\title{
Richard Digby McKennell
}

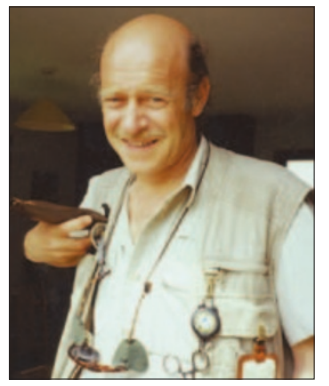

Richard Digby McKennell passed away on Monday 1 August 2005 at Chelsea and Westminster Hospital.

Born in Halifax, Yorkshire in 1946, he went to the local primary school before attending Bradford Grammar and then boarding school at Uppingham. In 1965 he began his dental studies. He enjoyed his years at King's College Hospital in full, where he acquired the high professional standards he espoused throughout his dental career. His social life was legendary, but he also demonstrated a commitment to the General Good, particularly through his editorship of The Cottager, the fortnightly voice of the student body. He only resigned as editor shortly before taking his finals and the magazine shows an evolving maturity and social awareness during his editorship.

His friends from those years remember a multi-talented young man - his jazz trumpet playing, his mechanical skills (dismantling and reassembling his Austin Sprite sports car in their shared living quarters) and his sporting forays. His vibrancy and charm enlivened all of their student days and his continuing friendship over 40 years was treasured.

In 1977 Richard took over the practice in Churton Street, Pimlico. It was here that through his hard work and dedication he was able to establish consistently high standards of dental care, while maintaining a friendly, family atmosphere among staff and

\section{Carol Ann Robinson}

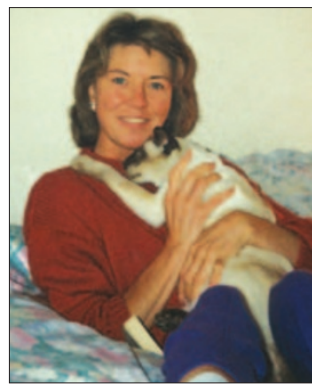

Carol Robinson died in King's College Hospital on 13 April after a long illness. Aged just 50, she bequeathed her estate to the BDA Benevolent Fund.

Born and educated in Croydon, Carol's career ambition from a very early age was dentistry. A keen and able sportswoman and amateur thespian, she fitted an active social life around her studies, and despite her school's attempt to divert her into nursing, she persisted with her dental ambitions and entered King's College Hospital Dental School in 1973, qualifying BDS in 1977.

An early postgraduate interest in maxillofacial surgery took her to House Officer posts at the Westminster Hospital and then St Thomas'. She progressed on to the Royal United Hospital at Bath as Senior House Officer before the start of her long illness precipitated a move to Bournemouth and a career in Community Dentistry. Later, moving back to her roots, she spent time in general practice and then community dentistry in Lambeth before illness forced her to give up the profession she loved.

She was delighted to return to King's (who told her 'once a King's dentist, always a King's dentist') on the KITS scheme

\section{He took great satisfaction in providing quality care to the benefit of each and every one of his patients.}

patients alike. He enjoyed practising all aspects of dentistry and developed an interest and special skills in endodontics. He took great satisfaction in providing quality care to the benefit of each and every one of his patients. He was truly a gentle man and a gentleman and employed dentists and support staff with a similar attitude to life.

Richard enjoyed country pursuits including shooting, fishing and birdwatching; he could name a bird by sight or sound. He loved his garden, his home, his family and his dogs. He was talented in many things and possessed extensive knowledge on a variety of subjects. He was creative, had a passion for gardening and was skilled at tying his own fishing flies.

Richard will be sadly missed by all who knew him: his wife Jean; his daughter Ruth; his sisters Maureen and Linda; and his many friends, colleagues, patients and the local community.

Donations if wished to Cancer Research, MacMillan Cancer Relief, The Royal Society for the Protection of Birds or The Game Conservancy Trust.

J. McKennell

\section{She will be remembered for her indomitable spirit, love of life, long phone calls, cats and Crystal Palace FC!}

until she could no longer work. Her love of learning stayed with her all her life; she gained the Diploma in Forensic Dentistry, graduated from Birkbeck College with a BA in History in 2002, took up computing with enthusiasm and had been accepted to start a law degree. Even in the face of major surgery she remained optimistic about her plans to complete the course.

Despite the many problems she faced in her life, Carol was always an enthusiastic supporter of her dental friends' careers and a keen converser on all things dental. In her last years she was a tireless and faithful worker for the Croham Road Baptist Church, whose members in turn supported her magnificently during her final illness. She will be remembered by the many friends who attended her funeral for her indomitable spirit, love of life, long phone calls, cats and Crystal Palace FC! 